\title{
BLAGO OCA RADOVANA: O NEZAVRŠENIM ČITANJIMA MELVILOVOG MOBI DIKA
}

Ep o putovanju, Mobi Dik, i danas je predmet istraživanja jer ga je nemoguće pročitati u ključu jedne književno-filozofske koncepcije; svaku mogućnost uvek prati i suprotna, subverzivna struja sumnje i neverice. Time se delo otvara i ostaje nedovršeno kao stalno pitanje konačne metafizičke slike čoveka i sveta što mu daje neprolaznu vrednost kao izazovu, nadahnuću, intelektualnom putovanju. Rad se načelno sastoji iz dva dela: jednog, u prilog otvorenosti Melvilovog dela, i drugog koji ukazuje na još jednu intentio, ovoga puta prethodnog čitaoca. Njegovi znaci na marginama nisu ništa manji inspiratori budućim čitaocima od samog dela.

Ključne reči: Mobi Dik, nedovršeno čitanje, prethodni čitalac.

„....reče Vildad ne dižući oči, a zatim nastavi da mrmlja "jer gde je vaše blago, onde će biti i srce vaše." (103)1

Sred razgovora, prof. Vidosava Janković je zastala, pogledala me iskosa a izravno pitala, „Dragana, vi ne prihvatate ovo mišljenje o Melvilu, zar ne?"

Nešto mi je zastalo u grlu. Nešto sam promucala. A nešto sada pišem, mnogo godina kasnije, kao da vraćam stari dug.

1 Svi navodi iz Mobi Dika iz izdanja datih u literaturi i u tekstu. Moto je, u samom delu, preuzet iz Novog Zaveta u kome se pominje na više mesta, recimo, u Jevanđelju po Mateju, gl. 6. Takođe, svi prevodi u radu su autorkini sem ako nije drugačije navedeno. 


\section{StARI DUG}

Nisam se mnogo opirala, tada, bar ne glasno, čitanju Melvila u formatiranim kontekstima, jednoznačnim, sa tek ponekom sumnjom, tu i tamo. Ali se zato celo moje biće, iznutra, bunilo protiv toga da mi se pročita knjiga i konačno „objasni” i da koncepcija „filozofije preko književnosti” (philosophy through literature) odnosi prevagu nad "filozofijom u književnosti” (philosophy in literature), bližoj Melvilu. ${ }^{2}$ Ova prva mogućnost, i to ne samo kada je u pitanju filozofija, već i druge, pred-postojeće, već-potpuno-razuđene-teorije - teološke, političke, kulturalne - predstavljala je oblik završenosti pa je i otimala, između ostalih, i drsku, problematičnu sagu o lovu (poteri, progonu, pogromu) na belog kita od onih, željnih da i sami sa njom, imaginativno, proputuju. To bi ih putovanje prevelo, melvilovski rečeno, iz statusa čitaoca-posmatrača (ocean-gazers), nagriženih zaludnom čežnjom za znanjima izvan horizonta, u status čitaoca-učesnika ili (sa)govornika, sposobnih da zarone u pustolovinu njegovog dela:

Volim sve ljude koji rone”, pisao je Melvil u pismu Dukinku, „svaka riba može da pliva blizu površine, ali je potrebno biti veliki kit da bi se zaronilo na dubine od pet milja i više [...] (govorim o) svim skupinama misaonih ronilaca (thought-divers) koji su, od postanka sveta, umeli da zarone i ponovo izrone zakrvavljenih očiju. (Davis - GILMAN 1960: 78)

Ništa od toga nisam rekla tada ali je prof. Janković sigurno sve pročitala u mojim umornim očima: to duboko ronjenje po knjizi, i po još nekim nezavršenim čitanjima. I moj otpor prema tumačenjima da negde, tamo, postoji neki ključ, šifrarnik, neki „istiniti sadržaj” (truth

2 Tačnije, ,filozofija u književnosti” podrazumeva da je predmet filozofske namene dato književno tumačenje u smislu zamišljenog, umetnički stvorenog sveta, „odnos u kome je filozofija podređena nameri i funkciji književnosti pa se, shodno tome, aspekt definisan kao filozofski (...) može identifikovati kao integralni deo, ili, kao delimični konstituent estetske vrednosti.” Na drugoj strani, ,filozofija preko književnosti” upućuje na „upotrebu imaginativnih književnih formi kao sredstava izlaganja radi što efikasnije komunikacije filozofskih koncepcija već u potpunosti razrađenih". (LAMARQUE - OlSEN, 1994: 391-392). 
content) koji pakuje Melvilovo delo u referencijalni format, ${ }^{3}$ odvodeći ga, pri tom, iz fiktivne, književne dubine u „sramni plićak” površine. Uz pomoć metode, učitelja ili gurua.

\section{DOBA VODOLIJE: NO TEACHER, NO GURU, NO METHOD}

Bile su to mlade godine, godine nepripadanja. Svet i njegove opsene su se merile po distanci koju si zauzimao prema njima. Doba je bilo politički klizavo, vodolije su ronile i davile se u ratu sa rakovima i škorpijama, a Lusi odlazila na nebo, sa ili bez dijamanata. Bilo je in biti out, jezik se oštrio na već ruševnim ideologijama, farmerice su se prirodno cepale, a u ušima je bubnjao glavni čovek osamdesetih, Van Morison (Van Morrison), i njegova poslanica „U vrtu” ("In the garden”, 1986).

\section{3. ... I OTAC}

Na letnjem pljusku, ili „kad god mi (je) vlažni novembar rominja(o) u duši” (), kao „biće, načisto puklo” (“a creature all in rapture”) (Morrison 1986) pod raznim pritiscima, i crnim mislima, ponavljala sam mantru o bezučiteljskom svetu, samosvojnosti i ono malo preostalog morala koji me je sprečavao da skidam ljudima šešire sa glava, na kišnim ulicama:

Ne! za učitelje, gurue, metode!

Tako je govorio Ven the Men, kako smo ga zvali.

3 Referirajući na razmišljanje (Stenlija) Kavela o tome kako književnost i filozofija usmeravaju pažnju na ista fundamentalna pitanja, Gibson tvrdi da kognitivna dimenzija književnosti leži u „njenoj sposobnosti da deluje na istine koje već posedujemo". Fikcionalni narativ možda nema sposobnost da iznosti argumente zasnovane na van-književnim istinama ali može da iskazuje „obrasce isticanja, vrednosti i značaja" pokazujući nam šta je to što se "stavlja na kocku' ako zauzmemo određen intelektualni stav". (Evans 2013). Navodi iz Gibsona (GIBSON 2007: 102) 
Govorio je: ovde smo samo ti i ja i priroda, „i otac u vrtu”.

Ne! govorili su, davno, i buntovni, setni i odmetnuti Hotorn, i Melvil,

i ti i ja,

ali je pometnju, i tada, unosio „otac u vrtu”.

\section{PESAK \& TRAVA, DIVLJE \& PUSTO}

„Ti” i ,ja” smo lako mogli biti dva nekadašnja berkširska suseda, Hotorn i Melvil, koja su se, posle stanke od tri godine, srela jednog prohladnog dana, 12. novembra 1856, kako zapisuje Hotorn u svom dnevniku, i pošla u „prilično dugu šetnju” obalom Irskog mora, kraj Sautporta: „pesak \& trava. Divlje \& pusto. Jak vetar. Dobar razgovor”. (PARKer 2005: 300) Melvil je u to vreme zaposlen u američkom konzulatu u Liverpulu, i, kako svedoči dnevnik, izgleda kao i obično „sem što je malo bleđi i možda malo tužniji” (PARKER 2005: 300) - „Zapušten, ${ }^{4}$ brbljiv, dvosmislen" (PARKER 2005: 300):

Spustili smo se u jedno udubljenje među peščanim dinama (štiteći se od jakog, hladnog vetra) i zapalili cigarete. Melvil je, kao i uvek, započeo da raspravlja o Proviđenju i budućnosti, i svemu što leži van domašaja ljudskog razumevanja, i obavestio me je da je on 'poprilično rešen na samo-uništenje'; ali još uvek ne izgleda kao da ga je to predviđanje umirilo; i, mislim, neće se on ni smiriti dok se ne domogne kakvog definitivnog uverenja. Čudno koliko istrajava - a istrajavao je od kada sam ga upoznao, a verovatno i dugo pre toga - u lutanjima tamo-amo po ovim pustarama, jednako sumoran kao ove peščane dine između kojih smo sedeli. On ne može niti da veruje niti da se oseća udobno u svom neverovanju; a previše je pošten ili hrabar a da ne pokuša da čini jedno ili drugo. Kad bi bio religiozan čovek, bio bi jedan od najiskrenije religioznih i smernih; on je vrlo uzvišene i plemenite prirode i mnogo vredniji besmrtnosti od većine nas. (PARKER 2005: 300)

Ali, religiozan, nije bio. Ni učitelj, ni guru. Kao u malopređašnjim stihovima, u njemu su se čovek, priroda, ali i „otac u vrtu”, prelili u skup filozofskih i teoloških pojmova koje je, kako navodi Parker, preveo u miltonovske reči: „zacrtana sudbina, slobodna volja, apsolutno pred-

4 Piše Hotorn, „On je osoba vrlo džentlmentskih poriva u svakom pogledu sem što je pomalo heterodoksan u pogledu čiste odeće”. (PARKER 2005: 300) 
Dragana R. Mašović: Blago oca Radovana: o nezavršenim čitanjima Melvilovog Mobi Dika

znanje" a zapisao u svom dnevniku od 13. oktobra 1849 ("Fixed Fate, Free-will, foreknowledge absolute" prema PARKer 2005: 300). A onda ih je, opet, preveo u veliko okeansko putovanje, epsku fantaziju, kojom je razbio i poslednji bastion jednoznačne, zatvorene, totalitarne, „crne” misli - metod - a ostavio knjigu, otvorenu.

\section{IZMEDU UBEDENJA I SUMNJI}

Melvilov otpor prema metodu, odnosno, sistematizovanoj misli kao potki oko koje bi se plelo književno delo, na taj način koherentno i kompaktno, mogao se delimično pripisati njegovoj negativnoj sposobnosti, odnosno, kako je definisao Kits, sposobnosti „da živi u neizvesnostima, misterijama, sumnjama a bez ikakvog iritirajućeg potezanja za činjenicama i razumom”, zadovoljan „sa polu-znanjima”. (KEATS 1818). S tim što je Melvil i te kako potezao za činjenicama, i te kako potezao za razumom a isuviše bio daleko od zadovoljstva poluznanjima. Sasvim suprotno: njegovi likovi u epu o potrazi za belim kitom daleko su od malodušnosti, kompromisa ili samozadovoljnog kvajetizma; oni su otvoreni prema svim iskustvima (ma kako pretećim po njihova uverenja ili čak živote) u potrazi za horizontom kognicije, za celovitim, apsolutnim istinama, od pripovedača Ismaila do glavnog, kapetana Ahava, uz hor raznoraznih glasova sa kopna i sa mora. Oni predstavljaju plejadu stavova, epistemioloških pozicija, od zdravorazumskih do posvećeno-fanatičnih. I svaki od njih ima svoju tezu a većina i anti-tezu, upravo kako pokazuje Dejvid Evans (David Evans), kao što i sam Melvil, u međuprostoru između vere i neverice, oscilira u narativnim potezima, ironijskim i samosvesnim digresijama, žanrovskim preklapanjima, mešanju književnih vrsta i podvrsta, i, uopšte, u talasanjima o kojima piše Hotorn. Rastrzan između uverenja i sumnje, između potrebe za pripadanjem i nemogućnosti prihvatanja tog pripadanja, on jedino uspeva da uspostavi ravnotežu u zauzetim gledištima tako da niko, od grdosije kita do opsednutog kapetana, od uljudnog kanibala Kvikvega do prizemne posade, ne odnese prevagu 
nad svetom koji, ako tone, tone u celosti, ostavljajući za sobom jedino priču o svom (samo)uništenju.

Da sumnja ostaje otvorena i da se ne može pripisati čak ni jednom prepoznatljivom filozofskom pravcu kao što je skepticizam (iako i on rezonira u delu, kroz likove, esejističke komentare i evokacije značajnih predstavnika), Evans pokazuje mnogim primerima odsustva „gurua i metoda": njihovo mesto zauzimaju inverzije, kontrasti, višesmislenosti, oscilacije.

Pod inverzijom se u Melvilovom delu podrazumeva preokretanje tradicionalnih uverenja i postupaka; na taj način, oneobičava se svet njegovog dela i svet izvan njega, izbačen iz udobnog ležišta navika, mentalnih, kulturalnih. ${ }^{5}$ Upravo kako je, ocenjujući način na koji se hrišćanski nauk našao upleten u apokaliptičnu Melvilovu sagu, zaključio jedan kritičar:

Melvil je bio veliki biblijski neskripturalni pisac. Sve je moguće, a zaista je i uloga čitaočevog puta da to i očekuje, to izvrnuto (inverted), okrenuto naopačke, pokidano i rekonstruisano u svoje suprotno ogledalo. U Melvilovim rukama sve biblijsko što se uopšte može doživeti - sasvim sigurno i hoće. (CADY 1983: 33-35)

\section{IZBAČENI IZ LEŽIŠTA}

Jedan takav preokret, da pomenemo, jeste i novo određenje koncepta „kopna” i „okeana”. Po iskustvenoj, kulturalnoj navici, kopno je znak spasa, spasenja, i prateće sigurnosti, udobnosti, stabilnosti. Suprotno tome, okean je neprekidno kretanje, nesigurnost, neizvesnost: ne čudi da su drevni bogovi pokazivali svoje pravo lice tek na talasima. U Mobi Diku je suprotno: kopno je izdajničko i robovsko, stagnacija, konformizam, materijalizam i lažna sigurnost, život u neznanju i duhovnoj oskudici: bogatstvo se otvara tek na pučini (ili, melvilovski, u

5 Među mnogim radovima koji ukazuju na destabilizaciju tradicionalnih narativa posebno mesto zauzimaju biblijski motivi, očigledni u manjim strukturama dela (propovedi oca Mepla) ali i na širem planu romana, posebno priča o Jovu (čija je inverzija priča o Ahavu ili anti-Jovu) (videti Schippe, Stetson, 2006; PAffenroth, 2004) i priča o Joni. 
„beskopnenosti”), gde se iskušavaju ne samo božje moći nego i ljudske, i, možda, krije ili ne, neka pretpostavljena, konačna istina. Ona je, u biti, na strani okeana jer se „na pučini nalazi najviša istina, gde obale nema, gde je beskrajnost kao bog” (137). Što na čas vraća na arhetipsku sliku vrta, tebe i mene i prirode... i oca koji jeste i nije beskrajnost, prisutnost i odsustvo.

Sličan preokret doživljava i simbolizam boja, promena njihovih asocijativnih značenja: belo je, od davnina, simbol nevinosti, čistote, dobrote, u zapadnoj kulturi. Kod Melvila se belim boji veliki kit, ultimativna misterija, kojoj se može pripisati krajnje dobro ili, verovatnije, zlo ali koja, na kraju, odnosi sa sobom sve aktere velikog lova, pa i sam brod (uz jedinog preživelog, spašenog zahvaljujući crnom dobrom čoveku). ${ }^{6}$ Belo je, i u drugim njegovim delima, iako kulturno dominantno, opako a crno nedovoljno poznato ali uglavnom dobro. Ništa manje nisu probitačne inverzije božanskog i đavolskog, kada, primera radi, kapetan Ahav krsti harpun, umočen u ... krv, u ime davola a ne boga. ${ }^{7}$

Ovi primeri su dobro poznati, uz mnoštvo drugih, koji nalažu stalnu budnost u čitanju dela (ništa manje od pozornosti mornaraosmatrača na visokom jarbolu), kao i njegovu protejsku prirodu. Nju usložnjava i ono što Džonatan Krimins (Jonathan Crimmins) naziva „obrascem inverzija” (a pattern of inversions) kada se žanrovi „gnjezde" (nested) jedni u drugima kako bi destabilizovali naraciju i omeli je da se usidri u jednu jedinu koncepciju. Otud se u delu prepliću, pre svega, fikcionalni i nefikcionalni žanrovi, a zatim esej i drama (tragedija), romansa i roman, ali i propovedi, naučni elaborati, elementi gotike i fantastike, i sl. Slično se mešaju i stilovi: od diskursa mornara, mornarske (i opšte) svakodnevice preko izravnog izlaganja do visoke

6 Kao najvažnija, danas, i s obzirom na stanje savremenog sveta, jeste Melvilova inverzija tadašnjeg i viševekovnog uvreženog odnosa prema Drugom, oličenom u Kvikvegu čija plemenitost nadilazi uskogrudost belog čoveka. Pripovedač Ismail, skeptičan prema naravi belih hrišćana, zaključuje već na prvim stranicama romana da je „bolje spavati sa treznim kanibalom nego sa pijanim hrišćaninom” (40).

7 „Ego non baptismo te in nomine Patris, sed in nomine diaboli - besno zaurla Ahav kad gadno gvože prljeći stade gutati krv pri krštenju”. (590) 
retorike, lirskih izliva, deskriptivnih izveštavanja, idiomatske proze, fantastičnih projekcija ali i komentara na aktualne događaje i pisanja. U svom tom komešanju, destabilizuje se „svet broda” (,svet kopna”) samosvesnim komentarima, oneobičavajućim metaforama, iznenađujućim poređenjima, duhovitim opaskama i stalnom ironijom - kao da sam pripovedač, Ismail, podriva svoje stvaranje, i, poput Penelope, razgrađuje ono što gradi. No method.

Sličnu ulogu imaju i kontrasti - da unesu sumnju, podriju isključivosti, uključujući i one u samoj naraciji, i da, istovremeno sa konstrukcijom, izvrše auto-destrukciju. Opštem utisku subverzivnosti doprinosi i jačina kontrasta, distanca između suprotstavljenih ekstrema. Tako se kontrastriraju epistemiološke pozicije koje likovi zauzimaju; na jednom kraju je hubristički, prkosni Ahav, sa tvrdnjom da istina „ne poznaje granice” i da mu je istina belog kita i te kako dostupna, u njegovoj (anti)herojskoj opsesiji, dok je, na drugom kraju, Ismailov mnogo ponizniji stav, „Ne poznajem ja njega, niti ću ga ikad znati” (459). Drugim rečima, na jednom kraju je izdvojeni i asketski vođa, Ahav, preteča monomanijakalnih lidera 20. veka, a na drugom posada u homosocijalnoj mreži, sa svojom putenošću, energijom, vitalnošću i solidarnošću, žudna da zadovolji svoje „obilnije, dnevne apetite” (261).

Oscilacije u pisanju, pokazuje Evans, očite su u širokom luku, od šekspirovskih solilokvija kapetana Ahava, do smirenog, poigravajućeg Ismailovog diskursa (ili, kako Melvil navodi u jednoj potonjoj metapesmi, od „ludačkog krešenda” do „tužnih nota”) ${ }^{8}$. Čitanje takvog teksta je, nastavlja Evans, nalik na plovidbu mornara po uzburkanom moru, mornara koji se upinje da se uhvati za nešto dok mu paluba izmiče pod nogama - što je nalik na stanje samog Melvila u Hotornovom opisu. Slična slika važi i za druge vidove dela, „bipolarne”, kako ih kritičari nazivaju ističući ekstremne promene raspoloženja, ekstremne stilske

8 Herman Melvil, „Eolska harfa” (,The Aeolian Harp”), u stihovima: „Počuj harfu u jauku prozora /Pod udarima vetrova sa mora:/ Kako vrišti u ludom krešendu -/Pa umire u notama tužnim!", https://www.poemhunter.com/poem/the-aeolianharp-2/ 
i žanrovske promene, od „dezintegracije do koherencije”, ${ }^{9}$ od „depresije do manijakalne uzavrelosti”. ${ }^{10}$ Ovi i drugi brojni primeri ukazuju da Melvilovo delo prožimaju suprotstavljene tendencije, a da je tako stvorena dramska tenzija, u biti, „negativna”, rečeno Kitsovim jezikom i stoga - misteriozna, izazovna.

Ali, čak i ovakav pregled „bipolarnih” crta kao potvrde njegove „neskripturalnosti” već je sam po sebi podložan sumnji i daljoj analizi - ako smo, primera radi, ukazali na inverziju belog i crnog, ili boga i đavola, onda je teško zatvoriti ovu ocenu, upakovati je u kritički format a prenebregnuti opise koji remete binarnu matricu pa se, u jukstapoziciji, nalaze i satanske i Hristove odlike u prikazu Ahava, i sl. Takvim kombinacijama, višesmislenostima, obiluje delo i potvrđuje Kitsovu pretpostavku o multivalentnoj istini. ${ }^{11}$

\section{OD GVOŽĐA DO PERJA}

Da je osciliranje među ekstremima svojstveno romantičarima naglasio je i Kits u jednom pismu svom prijatelju, Bendžaminu Bejliju, iz 1818. (na godinu pre Melvilovog rođenja):

9 Džon Brajant (John Bryant) je pisao o „flip-flop” kretanju u Melvilovoj prozi, između dezintegracije i koherencije, (BRYant 1993: 184, 200).

10 Komentar Džona Apdajka (John Updike) u kome se dalje kaže da su oscilacije zapravo „puls koji se može osetiti u hrabrim izlivima njegove proze” (UPDIKE 1997: xiii).

${ }^{11}$ Možda na ovom mestu treba dodati i brojne odlike mikrostruktura stila koja zamagljuju polaritete, prebacuju, da kažemo jezikom romantičara, „veo” preko izravnih slika, jezikom čija je sintaksa zbunjujuća i neretko nadrealna, stvarajući atmosferu sanjalačku i tajanstvenu; uz more arhaizama, latinizama, neologizama, posebno imeničke reči sa sufiksom „ness” (bezobalnost, bezkopnenost); zatim, pripovedanje obiluje tropima a nisu retke ni oksimoronske konstrukcije u karakterizaciji (Ahav je, tako „dobar čovek koji psuje” (106) a Kvikveg „,̌ist ljudožder koji prijatno izgleda” (40) dok je za kapetana Pilega Ahav „sjajan, bezbožan čovek što na boga liči” (105). 
Dve najdominantnije misli u ljudskom umu su dva pola njegovog sveta oko kojih se on okreće pa je, za njega, sve ili južno ili severno njihovim posredstvom - Mi smo samo na tri koraka daleko od perja do gvožđa. A sad, moj dragi prijatelju, moram ti jednom zauvek reći da nemam nijednu ideju istine o ijednoj od mojih misli - ja nikada neću biti logičar jer ne marim da budem u pravu, kad završim sa polemisanjem i kad sam u pravom filozofskom raspoloženju. (KEATs 1818)

Kao i Kitsa, i Melvila zatičemo na razmeđi polova, u nekom polukoraku, kako je ukazao Hotorn, vere i sumnje, ili, kako je ukazao Emerson, istine i opuštanja.

\section{IZMEĐU ISTINE I OPUŠTANJA}

Slično je izrazio i Emerson, u eseju „Intelekt”:

Bog nudi svakom umu izbor između istine i odmora. Birajte šta vam drago, oba ne možete imati. Između njih, kao klatno, čovek oscilira. Onaj u kome dominira ljubav prema opuštanju [...] dobija odmor, komoditet i ugled; ali on zatvara vrata istine. Onaj u kome dominira ljubav prema istini, taj će se truditi da bude daleko od svih sidrišta i taj će ploviti. (EMERSON 1841)

A ta je plovidba, za Melvilove čeznutljive posmatrače okeana koje nagriza nervoza „opuštanja i komoditeta” i koji bi je rado zamenili za pustolovine daleko od sidrišta, jednaka čitanju, sa olovkom u ruci, sličnog tragača, raspetog između želje za sigurnošću dekodiranog teksta i neizvesnosti nikad dovršenog ili, čak, prekinutog putovanja.

\section{NAVIGACIONI POKAZIVAČI}

Heteroglosna i palimpsetska priroda Mobi Dika kao da je stvorena za velika čitalačka putovanja; ako se tome dodaju samosubverzije, podrivanja privremeno uspostavljenih značenja i slični znaci lebdenja između mogućnosti, dobija se šlegelovski spoj imanja i nemanja sistema, jedinstvo potpuno disparitetnih elemenata koji, u tom sjedinjavanju, indukuju kreativnu, produktivnu tenziju. To je, ujedno, vid 
romantičarske ironije koja se, u estetskom smislu, iskazuje u „želji za celovitim umetničkim delom ali i ironijskim napuštanjem dela (parabasis) u trenucima parodijske disolucije". (CRITChley 2004: 135) Taj dvosmerni poriv, ka samostvaranju i samodestrukciji, metaforično je ilustrovao i sam Melvil, u poglavlju „Jedan venjak u Arsacidama” kada bog-tvorac poprima oblik tkača, sa plodnom zemljom kao razbojem i na njemu raskošnim ćilimom „gde su brkovi sa lijana sačinjavali potku i osnovu, a bujno cveće šare” - u toj nabujaloj lepoti, bog-tkač, nevidljivi, ne može da drži tkanje pod kontrolom: „čunak leti, šare iskaču i dalje sa razboja; izrađeni ćilim kao bujni potok stalno juri dalje” (543). Pa i Ismail, u tom isprepletanom haosu, i kad uzme klupče kanapa i krene da luta po kosturu mrtvoga kita, među „njegovim mnogobrojnim krivinama, zasenčenim nizovima stubova, i po njegovim lugovima” (544), na kraju utvrdi da „ničega tamo nije bilo sem kostiju” (544). Zato i čitanje o njegovom putovanju, i lutanje kroz lavirint reči, ne poseduje nikakav sveobuhvatni sistem. Umesto njega, na kraju čitalac/kritičar, raspolaže samo „dimenzijama kostura”, ili, kako ih naziva Evans, navigacionim pokazivačima (navigational pointers) dok se kreće između uticaja, književnih i filozofskih, Melvilovog dela - a pritom zna da nijedna njegova kritička misao ne može biti krajnja ili neotudiva.

\section{FLUIDNO DELO I NJEGOVI NAMERNICI}

Čitaočeva plovidba (ili ruta) je vođena samo pokazivačima, i to ne samo u jednom izdanju već, kao što to biva, po rečima Džona Brajanta, u takozvanim „fluidnim tekstovima”, u mnogobrojnim „materijalnim verzijama” (uključujući brojne prevode), i u rasponu od samih događaja o kojima se pripoveda preko višemesečne pustolovine pisanja do pustolovine čitanja - a tu poslednju prolazi sam čitalac, korak po korak, zajedno sa glavnim junacima. I svi oni, učesnici u književnom fenomenu, mogu imati slobodu navigacije, između zadatih znakova, odnosno, slobodu interpretacije. Na nju je, međutim, upozorio Eko, dižući glas protiv izvesnih neverovatnih, neodgovarajućih ili čak pot- 
puno nemogućih interpretacija teksta (koje Eko čak, u ekstremnim slučajevima smatra paranoidnim preteranim interpretacijama (overinterpretations)) (BoNDANELLA 1997:129). Upravo kako je i ukazao u svojim Tanerovim predavanjima: „Ja prihvatam stav da tekst može imati veći broj smisla. Ali odbijam stav da tekst može imati svaki smisao" (Bondanella 1997: 130).

Sa grehom tzv. preterane interpretacije sreću se profesori književnosti u svojoj nastavnoj praksi, na kursevima čitanja i tumačenja književnosti, skoro svaki dan. Bore se i sa sobom i sa svojim sagovornicima protiv „učitavanja”, izvođenja preširokih hipotetičkih referenci ili čitanja teksta kroz sebe i u odnosu na sebe. Samim tim se trude da navedu i sebe i druge da potvrdu o svom mišljenju, pre svega, nalaze u pojedinostima u tekstu.

Danas, međutim, znamo da je svako čitanje metatekstualno i vodi u takozvanu „preteranu” interpretaciju. A nju, pak, Harold Blum vidi kao kreativnu. To paralelno postojanje „sebe” i dela, i paralelno odvijanje svojih misli i glasova u delu, i njihovo susretanje, povezivanje ili razdvajanje, za Bluma su odličja kreativnosti uspostavljene međutekstualne veze: ti se tekstovi međusobno nadahnjuju i njihovo preplitanje vodi u novu, inovativnu, svežu obradu.

Međutim, između te dve polarnosti, Ekoove osude preteranosti i Blumove pohvale sažimanja stvarnosti „sebe” i fiktivnosti dela, mogu se naći još neki glasovi u vrtu, ispražnjenom od metode, gurua i učitelja.

\section{GLasovi u VRTU}

U međuprostoru, između autora, čitaoca i dela, može se pojaviti još neko. Može se naći, u pred-elektronsko vreme, u štampanom formatu, neki njegov znak. Kao što nepismeni Kvikveg ostavlja svoj znak, na telu Mobi Dika. U američkom izdanju, to je pokrstica x a u starijem, srpskom, to je beskonačnost, $\infty$ (117).

Sa sličnim znacima, rasutim po knjigama, upisanim perom ili olovkom, otvaraju se još neka putovanja, sa nekim drugim tumačima. 
Dragana R. Mašović: Blago oca Radovana: o nezavršenim čitanjima Melvilovog Mobi Dika

Kao i svi drugi, i ovi slepi putnici, putuju i čitaju (se). Nazovimo ih Prethodni Čitaoci. A njihovo čitanje ispisala je...olovka ${ }^{12}$

\section{2. ...I OTAC}

Godine 1969. beogradska Narodna knjiga izdala je Melvilovog Mobi Dika u prevodu Milana S. Nedića a sa predgovorom Vidosave Janković. Iste godine, moj otac je kupio tu knjigu, krenuo da njome putuje, ali je, na početku tog i bukvalno nedovršenog putovanja, otišao, iz vrta, zauvek.

Moj otac ili Otac (ti, ja, anti-Ahav, Ahav, Jona, Jov, bog, davo), za mene, u ranom detinjstvu, bio je ništa manja tajna od one koja je proganjala Melvila, i još neke. A kada sam, mnogo godina kasnije, otvorila knjigu i, neočekivano, pronašla njegove znake, krenula sam da čitam na dva nivoa: Melvilovo delo i čitaoca Melvilovog dela, njegovo podvlačenje crvenom olovkom, tankom, stidljivom i čak, jedva vidljivom, po kojoj je moja nemilosrdna, profesorska, crna, udarala iz sve snage. Snage izvežbane na čitanjima Drugih Prethodnika, tajne azbuke prof. Brankice Pacić i još tajnijeg kodnog sistema prof. Vučkovića.

Ti moji kapetani, moj otac, profesori, zauzeli su meduzvezdani prostor a ostavili navigacione pokazivače: upitnike, upadice, pribeleške, umetnute papiriće, čak, da se lako okrenu na času, ili pročitaju u gluvo doba noći, kad ne pomaže ništa - a pomaže. Sve su to bila virtualna izdanja jedne ili više knjiga, one Melvilove, ili o Melvilu, ili o sebi, tu, u Melvilu. Nikad završena ili, bolje, u stalnom nastajanju.

12 Putovanja knjiga u raznim izdanjima, u raznim kulturama, a prema važećim zvezdanim konstalacijama, navela su prof. Mladena Jovanovića da me upozori, u vreme mog rada na Fokneru: „Pazite, polako sa Foknerom i Avesalomom. Možda ne znate, tada je Fokner dobio naliv pero i punio ga naizmenično plavim, pa zelenim, pa crnim mastilom a da ga nije pažljivo brisao - samo ga je punio i pisao - pa se na rukopisu knjige vide promene boje, u nijansama. Zato, oprezno!" Štampa je to izjednačila, izbrisala te nijanse. Za dobar deo sveta, Fokner je ostao jednobojan, tamo gde se poigravao. Tu i tamo, ipak, jednobojnost su razbile boje, njegovih čitalaca. 
Po tom virtualnom prostoru, krenula sam da tragam. Kao i Melvil, i Ismail. I Redbern. I Din Morijariti. I sluđena generacija sluđenih vodolija, tih sedamdesetih, osamdesetih, sa dna lešine jednog raspuklog levijatana, ali, kako bi rekao Keruak, sa pogledom uperenim naviše.

\section{3. $\mathrm{ON}_{\mathrm{N}}$}

Otac ga je podvukao, odmah (Ismail). Ali i ne i prve dve reči koja sa tom, trećom, čine često navođenu celinu i jasno ukazuju na poprimljeni, konstruisani identitet. Samo je zacrveneo ime, možda zaintrigiran izborom... Ili iz neke lične, još dublje želje, da se, na grozničavom putovanju koje sledi, po talasima ovih stranica, i on, tim imenom, prozove. Ili na nekim drugim talasima o kojima mi, kraj njega, nismo ništa znali ni slutili. Da li je moguće, pitala sam se, da je i on, odnekud, bio izgnanik, odbačenik, možda nesrećnik, možda...?

Sve postaje sumnja, u čitanju olovke. Ona je akt del arte, bez metoda, analitike, pedanterije, sitničavosti. Prethodni čitalac se u njoj objavljuje kao skup pitanja, bez odgovora, akt asindentonije, iza koje ostaju slutnje, varke, rekao bi Melvil. Najposle, tu je, odista, sve postalo sumnja. I u svemu tome se krije Melvilova beskopnenost jer nema ničeg čvrstog u tom odnosu o koje bi se misli oduprle, odbile, odvojile i krenule u nepreglednost.

Zatim, olovka crveni Ismailovu odluku da „uvek ide(m) na more kao mornar". Sumnja pada na odluku. Ili je to stav? Namera? Ideologija? Priznanje? Kajanje? Rezignacija? Samo-omalovažavanje? Poštovanje - za druga mornara? Ismail se konstituiše kao „mali čovek” u odnosu na titanskog odmetnutog nadčoveka, Ahava; bez želje za isticanjem, bez narcističke opsednutosti, ali sa dovoljno cinizma prema Suđajama koje su drugima namenile veličanstvene uloge. Da li je On/ Ismail ogorčen? Da li se pomirio sa svojim umanjenim jastvom? ...

Zašto je, potom, podvukao, „Ko nije rob? To vi meni recite” (18)?:13 Njegovo vreme bilo je stameno kao klisurina, podvižničko, duboko

${ }^{13}$ „Budući da Ahav nije jedini lik vođe u romanu; ima ih puno, ali je samo on nadmoćni gospodar i diktator na izolovanom brodu miljama daleko od kopna. Nje- 
sledbeničko prema svome Ahavu koji će umreti na pola putovanja ali ne pre nego što ubedi Pikvod da nastavi plovidbu do potpunog uništenja.

Ali, on je podvukao roblje. Isto su podvukli i moji profesori.

Olovka se sada zabada u jedan opštiji a provokativan stav: ,gotovo na isti način narod vodi svoje vođe i u mnogim drugim stvarima kad vođe to veoma malo i slute"! Opet, melvilovskom inverzijom, zaslepljene vođe ne vide da su vođene. Savremeni svet, međutim, uvida dinamiku odnosa vođe i sledbenika, reciprocitet koji je pisac predvideo mnogo decenija ranije. Stoga se i moć našla negde u poslednjim redovima, u pozadini, gde mornar preživi kataklizmu kapetana, broda, društva. I dok beli kit vuče na dno celi svet, poslednje što se vidi od broda je crvena zastava. Za istoričare-interpretatore to je podsećanje na tragični kraj francuske revolucije, ili na poraze iz 1848. Ili, uopšte, poraze idealističkih levičarskih ideala (koje su uzurpirali i kompromitovali ahavovski likovi). Ali On nije ni stigao do tog znaka-pokazivača - ali jeste do moći mornara-pripovedača-pisca.

\section{4. „ZAISTA, ZAISTA, BOGOVI!”}

Crvenilo iz olovke spušta se na osećaj kako je, „neka natprirodna ruka izgleda bila stavljena u moju ruku". Dug je put, u romanu, prešla ruka od detinjskog užasa pred „užasnom opsenom” preko „najužasnijeg straha” do neznabožačke ruke koja ga grli „užasno i pažljivo”. I ovde se vidi odlika čitanja prethodnog čitaoca a to je beskopnenost ili nikad dostignuto značenje: bez emotikona ili sličnih vizuelnih ili kratkih verbalnih komentara. Tanka nit olovke ne govori više od onoga što

govo vođstvo je kao i kod svih vođa u kontekstu gde drugi uticaji - religije, ideologije, prošlo iksustvo, primeri drugih modela vođstva i čak lični temperament - postoje u umu i sećanjima njegovih sledbenika. Taj kontekst je uspostavljen na početku romana, 'Ko nije rob?'. To je retorsko pitanje kojim nam Ismail ukazuje na sveopštost slugeranjstva i poslušnosti u ovom ili onom obliku kao i sveopštu potrebu da se prihvati prisustvo autoriteta, ako ne i liderstva. Svako u životu trpi udarce, da li od nastranih pomorskih kapetana ili drugih moćnika - ali tu istinu on prima u dobrom raspoloženju”. (CiulLa et al. 2008: 43) 
je njen izbor: podvučen je prvi užas, detinji, a kasniji užasi nisu: očito je sugerirano čitanje da sve jeste i može biti jedino tada... posle se samo ponavlja, kao farsa.

Poslednja podvučenost je ona iz bunta, otpora, disidentstva. U delu o propovedi oca Mepla o Jovi i kazni koja ga stiže za neposlušnost, olovka povlači himnu iz „ribljeg trbuha”. „A ako boga poslušamo, moramo ne poslušati same sebe (60/61); i baš se u tom nepokoravanju samom sebi i sastoji teškoća pokoravanja bogu”. Nešto se tu sklopilo: nepokor, sudar sa autoritetima, klinč sa bogovima. Podvučeno (ne)pokoravanje sebi.

Zaista, zaista, oče!

\section{INTERSTELAR}

U međuzvezdanom prostoru košmari, varke, slutnje i sumnje. Dole, na zemlji, dva prijatelja, ukotvljena između peščanih dina, pominju usud nedovršenosti. Melvil zapisuje „Bog neka me sačuva da ikad ma šta dovršim. Ova je cela knjiga samo jedan nacrt - ne, ona je nešto još manje, nacrt nacrta” (179).

Iz tog nacrta povlače se tumačenja, analize, ispitivanja jezičkih odlika teksta, manje ili više ekscentrične egzegeze, pokušaji da se „nacrtu nacrta” tek u interpretaciji daju obrisi jedne zaokružene celine, da se iščita politika, korektnost, rodni odnosi, latentne prisutnosti, kapitalizam u nadimanju, levica u odumiranju, ekološka briga za Mobija, „filozofija preko književnosti”, i sve ono što se može iskoristiti iz bogatog uloga Melvilovog iz generacije u generaciju. I sva su ta (u)čitavanja, ipak, ipak, primeri semioze, očuvanja, čitanja i ponovnog čitanja, književnog dela. Njoj čak i pripada prethodni čitalac, samozvanac, samosvojno zapisan na marginama, čak i onda kada nije više od improvizovanog, ad hoc, (ne)instrumentalizovanog komentara: podsetnik, aluzija, primedba, sećanje, poruka, želja da ga se nikad ne pronađe i ne pročita ili, suprotno, da ga baš pročita neki Budući. Pa je i ta poruka, iz međuzvezdanog prostora, konstituent književnosti. 


\section{Moć, KREATIVNA}

Jedna Emersonova misao iz ogleda o „Iskustvu” (1844) kao da je podvukla snagu tog hora učesnika u velikim književnim putovanjima:

Mi sumnjamo u naše instrumente (...) naučili smo da ne vidimo direktno već posredovanjem, i da nemamo sredstva kojima bismo ispravili ta obojena i iskrivljujuća sočiva. Možda baš ta sočiva imaju kreativnu moć: možda nema predmeta (objects).

Bog-tkač koji ne može da drži predivo pod kontrolom pa „šare iskaču”; Ismail koji luta po kostima lešine kita da ga spozna a spoznaje samo prazninu i ništa; otac zbunjen pojavom boga i Jova nakon tek srećno uspostavljenog bratstva druga Ismaila i druga Kvikvega... i mnogo toga još, izdanci su tih „obojenih i iskrivljujućih sočiva” bez kojih, naslućuje Emerson, naslućuje Melvil, možda baš ne bi ničega ni bilo. Ili bar ne bi bilo „konačne poslednje misli” koju mi, smrtnici, ionako nemamo, niti ćemo imati.

\section{Moć}

Ovde bi zastala prof. Brankica Pacić, zagledala se zamišljeno, za trenutak, $i$ kazala, „Nemojte zaboraviti, Dragana, onaj koji preživi je pripovedač, pisac!... A svi drugi odu!"

Alije i njeno putovanje ostalo nedovršeno, kao i putovanje prof. Vučkovića, i to pre nego što se na horizontu ukazala jedna stara/nova koncepcija čitanja, rešena da se vrati „prvim principima”. Pre nego što je, drugim rečima, neko od hrabrijih, kako bi rekao Apdajk, pozvao američku književnost da se vrati sebi, nakon što je dugo bila podredena konceptualnom proučavanju uz pitanja politike, društva, ekonomije. Uostalom, zar se nije Ričard Grevl (Richard Gravil) žalio kako se američka književnost prečesto čita u istom duhu kao bankarstvo (GRAVIL 2000: xii). U istom je diskursu, zato, $i$ primedba da vrede pokušaji da se tako obezvredenoj književnoj valuti - i njenim filozofskim ekvivalentima - ponovo vrati njena prava vrednost. 
Bila bi to divna vest za prof. Vučkovića. Koliko mi je samo puta ponovio, u vremena divnih knjiga, prevodenja, predavanja ali i slugeranjske književnosti, čauške kritike, pritisaka, redukcija, haosa, zuluma, političkih korektnosti i njihovih kanona, sa ove ili sa one strane, leve, desne, odasvud, gde su pisci gubili glave, a jurišnici jurišali:

„Šta god radili, Dragana, ne dajte književnost!"

Ne, dragi profesore, to blago se ne da. Taj beskonačni, beskrajni put obeležen slabašnim, zagonetnim, čudesnim znacima koji nude veru ali podstiču nevericu, bude želju za mirom a ispovedaju nemir medu pě̌čanim dinama i pišu se, vaistinu, čitanjem. Tako je pisao moj otac, tako su pisali moji profesori - a danas, verovatno ija.

\section{IZVORI I CITIRANA LITERATURA}

Bondanella, Peter. Umberto Eco and the Open Text: Semiotics, Fiction, Popular Culture. Cambridge: Cambridge University Press, 1997.

Bryant, John. Melville and Repose: The Rhetoric of Humor in the American Renaissance. Oxford: Oxford University Press, 1993.

CADY, Edwin. "'As through a Glass Eye, Darkly': The Bible in the NineteenthCentury American Novel”. Gunn, G. (ed.), The Bible and American Arts and Letters. Philadelphia: Fortress Press Edwin, 1983.

Ciulla, Joanne B., Hoyt, Crystal L., Forsyth, Donelson R., Goethals, George R., Genovese, Michael A., Leadership at the Crossroads, Santa Barbara (Cal.): ABC-CLIO, 2008.

Critchley, Simon, "Unworking Romanticism". Very Little... Almost Nothing. London: Routledge, 2004.

Davis, Merrell R. and Gilman, William H. (eds.), The Letters of Herman Melville. New Haven: Yale University Press, 1960.

Evans, David. "Scepticism at Sea: Herman Melville and Philosophical Doubt", DPhil Thesis, New College, University of Oxford, 2013.

GIBSON, John. Fiction and the Weave of Life. Oxford: Oxford University Press, $200 \%$.

GravIL, Richard. Romantic Dialogues: Anglo-American Continuities 1776-1862. London: Palgrave Macmillan, 2000. 
Dragana R. Mašović: Blago oca Radovana: o nezavršenim čitanjima Melvilovog Mobi Dika

Lamarque, Peter, and Stein H. Olsen. Truth, Fiction and Literature, Oxford: Oxford University Press, 1994.

Melvil, Herman. Mobi Dik. Preveo Milan S. Nedić. Beograd: Narodna knjiga, 1969.

PAFFENROTH, Kim. In Praise of Wisdom: Literary and Theological Reflections on Faith and Reason. London: A\&C Black, 2004.

Parker, Hershel. Herman Melville: A Biography, Volume 2; Volumes 18511891. Baltimore: JHU Press, 2005.

SchiPPe, Cullen, and Chuck StETson (eds.), The Bible and Its Influence, Fairfax, Va.: BLP Publishing, 2006.

UpDIKE, John. "Introduction”. The Complete Shorter Fiction. London: Random House, 1997.

\section{ELEKTRONSKI IZVORI}

Keats, John, "Letter to George and Tom Keats", Dec. 1818, https://genius. com/John-keats-negative-capability-letter-to-george-and-tom-keatsannotated/ 1.10.201\%.

Keats, John, "Letter to Benjamin Bailey", 13 March 1818, English History Net, https://englishhistory.net/keats/letters/letter-to-benjamin-bailey-13march-1818/ 1.10.201\%.

Emerson, Ralph Waldo, (1841) "Intellect", https://archive.vcu.edu/english/ engweb/transcendentalism/authors/emerson/essays/intellect.html/ 1.10.201\%.

MeLville, Herman Melvil, "The Aeolian Harp", https://www.poemhunter. $\mathrm{com} / \mathrm{poem} /$ the-aeolian-harp-2/1.10.201\%.

Morrison, Van, (1986), "In the Garden", http://songmeanings.com/songs/ view/35713/ 1.10.2017. 
Dragana R. Mašović

\section{MY FATHER'S TREASURE: ON UNFINISHED READINGS OF MELVILLE'S MOBY DICK}

\section{Summary}

An epic journey, Moby Dick, is still an object of research since it is impossible to read it as decoded in terms of a single literary-philosophical conception; each such possibility is always subverted by an opposite one, an undercurrent of doubt and disbelief. Thus, the novel opens itself up to the reader and remains "unfinished" for its lacking any definite metaphysical idea of man and world. This gives it an unfading value as a challenge, inspiration, intellectual journey. The paper consists of two parts, i.e., one discussing the openness of Melville's novel and the other pointing to another intentio, that of the previous reader. His marks on the margins are no less inspirational to the future readers than the novel itself.

Keywords: Moby Dick, unfinished reading, previous reader.

Univerzitet u Nišu

Filozofski fakultet

dmasovic@gmail.com 